\title{
The Association of Polymorphisms in Leptin/Leptin Receptor Genes and Ghrelin/Ghrelin Receptor Genes With Overweight/Obesity and the Related Metabolic Disturbances: A Review
}

\author{
Hamid Ghalandari ${ }^{1}$; Firoozeh Hosseini-Esfahani ${ }^{2}$; Parvin Mirmiran ${ }^{2,3, *}$ \\ ${ }^{1}$ Department of Clinical Nutrition and Dietetics, Faculty of Nutrition Sciences and Food Technology, Shahid Beheshti University of Medical Sciences, Tehran, IR Iran \\ ${ }_{2}^{2}$ Nutrition and Endocrine Research Center, Obesity Research Center, Research Institute for Endocrine Sciences, Shahid Beheshti University of Medical Sciences, Tehran, IR Iran \\ ${ }^{3}$ Department of Clinical Nutrition and Dietetics, National Nutrition and Food Technology Research Institute, Faculty of Nutrition Sciences and Food Technology, Shahid Beheshti \\ University of Medical Sciences, Tehran, IR Iran \\ ${ }^{*}$ Corresponding author: Parvin Mirmiran, Nutrition and Endocrine Research Center, Obesity Research Center, Research Institute for Endocrine Sciences, Shahid Beheshti \\ University of Medical Sciences, Tehran, IR Iran. Tel: +98-2122402463, Fax: +98-2122432500, E-mail: mirmiran@endocrine.ac.ir
}

Received: April 4, 2014; Revised: February 22, 2015; Accepted: April 27, 2015

\begin{abstract}
Context: Leptin and ghrelin are two important appetite and energy balance-regulating peptides. Common polymorphisms in the genes coding these peptides and their related receptors are shown to be associated with body weight, different markers of obesity and metabolic abnormalities. This review article aims to investigate the association of common polymorphisms of these genes with overweight/obesity and the metabolic disturbances related to it.

Evidence Acquisition: The keywords leptin, ghrelin, polymorphism, single-nucleotide polymorphism (SNP), obesity, overweight, Body Mass Index, metabolic syndrome, and type 2 diabetes mellitus (T2DM) (MeSH headings) were used to search in the following databases: Pubmed, Sciencedirect (Elsevier), and Google scholar. Overall, 24 case-control studies, relevant to our topic, met the criteria and were included in the review.

Results: The most prevalent leptin/leptin receptor genes (LEP/LEPR) and ghrelin/ghrelin receptor genes (GHRL/GHSR) single nucleotide polymorphisms studied were LEP G-2548A, LEPR Q223R, and Leu72Met, respectively. Nine studies of the 17 studies on LEP/LEPR, and three studies of the seven studies on GHRL/GHSR showed significant relationships.

Conclusions: In general, our study suggests that the association between LEP/LEPR and GHRL/GHSR with overweight/obesity and the related metabolic disturbances is inconclusive. These results may be due to unidentified gene-environment interactions. More investigations are needed to further clarify this association.
\end{abstract}

Keywords:Leptin; Ghrelin; Single Nucleotide Polymorphism; Obesity; Overweight; Body Mass Index; Metabolic Syndrome; Diabetes Mellitus, Type 2.

\section{Context}

Obesity has become a primary health issue, worldwide, and has stepped into epidemic scales $(1,2)$. The prevalence of obesity in Iranian adults and children is increasing. Taking into account that childhood obesity increases the risk of adult obesity, these statistics are really menacing for the next generations $(3,4)$. Obesity has long been recognized as one of the most significant risk factors for multiple nutrition-related non-communicable diseases, including: type 2 diabetes mellitus (T2DM), hypercholesterolemia, hypertension, and heart disease $(1,5)$. The causes of this deadly epidemic have not been established clearly and fully, yet. However, it is accepted by most researchers and health experts that "obesogenic" environment overall, which comprise the high calorie intake, coupled with the sedentary lifestyle imposed by 'modern lifestyle', is a major contributor to this condition $(5,6)$. Along with the environment, researchers believe that genetic factors also play an important role in the etiology of obesity, based on the observation that not all individu- als with a high calorie intake and low physical activity necessarily get fat (7). Complicated 'gene-environment' interactions are mostly responsible for the current "diabesity" epidemic (2, 5, 8-10). Family and twin studies show that $80 \%$ of body mass index (BMI) variation, $50 \%$ of T2DM risk, and $10-30 \%$ of metabolic syndrome risk are attributable to genetic factors (11). Among factors, affecting genetic variations, there are single nucleotide polymorphisms (SNPs). Although SNPs are not usually the sole disease-inducing factors, they can determine one's predisposition to special metabolic disturbances and, therefore, to diseases (9).

Among the biological factors playing a role in the etiology of obesity, there are appetite-regulating peptides, including endocannabinoid system (a system consisting of cannabinoid receptors and enzymes involved in the synthesis and degradation of endocannabinoids), ghrelin, neuromedin-beta, leptin, and uncoupling proteins (related to the efficacy of energy metabolism in the human

Copyright (C) 2015, Research Institute For Endocrine Sciences and Iran Endocrine Society. This is an open-access article distributed under the terms of the Creative Commons Attribution-NonCommercial 4.0 International License (http://creativecommons.org/licenses/by-nc/4.0/) which permits copy and redistribute the material just in noncommercial usages, provided the original work is properly cited. 
body)(6). Leptin and ghrelin are the two most significant energy- and appetite-regulating peptides.

In 1994, leptin was discovered to be the product of the "obese (ob)" gene and it was named after the Greek word, leptus, meaning thin. Leptin is produced predominantly in adipose tissue and is proportionally related to adiposity. Although leptin levels do fall with fasting and its absence is related to hyperphagia in animals and humans, several of these responses do not necessarily comply with changes in fat mass. This constatation suggests that the most significant role of leptin is in body energy homeostasis and not in meal-to-meal intake $(10,12)$.

Ghrelin is a naturally-occurring ligand to growth hormone secretagogue receptor (GHSR). Ghrelin is predominantly synthesized in the stomach. In contrast to leptin, ghrelin level in blood rises with hunger and is suppressed by feeding. Again, contrary to leptin, ghrelin is proposed to be more involved in short-term appetite regulation, although it also seems to be a factor in long-term energy homeostasis (12). Clearly, the production and secretion of these peptides and their receptors are regulated by their related genes. Multiple studies have been conducted regarding the effects of the common polymorphisms in these genes and the impact they may exert on weightrelated phenotypes. However, since the studies showed inconsistent results and few review articles have been published on this issue, we decided to review the recent papers that dealt with this subject.

The aim of this study was to investigate the association between the most common SNPs in the genes coding leptin and ghrelin and obesity and obesity-related health outcomes. We also expanded our research to SNPs in the genes coding their significant receptors (leptin receptor and GHSR).

\section{Evidence Acquisition}

The review of literature was started in November 2013 at the Faculty of Nutrition Sciences and Food Technology, Shahid Beheshti University of Medical Sciences, Tehran, Iran. We used the following keywords to search for the related articles: leptin, ghrelin, polymorphism, single-nucleotide polymorphism/SNP, obesity, overweight, BMI, metabolic disturbances, metabolic syndrome, and T2DM. These keywords were searched in the following websites/databases: Pubmed, Sciencedirect (Elsevier), and Google scholar. The search in databases was made using the following pattern: the exposures (i.e. the SNPs) AND the outcomes (e.g. obesity). The inclusion criteria used to choose the articles were: 1 ) the relevance of the article to the main title of the review. The studies should at least contain the common SNPs in leptin/leptin receptor genes (LEP/LEPR), ghrelin gene (GHRL), or GHSR and the following outcomes: BMI, waist circumference, adiposity (percentage of body weight, as fat), waist-to-hip ratio (WHR), serum lipid profiles and indicators of glycaemia/T2DM; 2) the articles should match the time frame determined, which includes all the articles published from 2009 to present (just to report more recent studies); 3 ) the originality of the articles, and 4) only case-control studies were selected to be analyzed. The reason why case-control studies were included in the review was that other kinds of studies were either too small in number (interventional studies) or too insignificant and region-specific (cross-sectional studies) to be report-worthy. Moreover, reviewing studies with the same design gives us the opportunity to draw a logical conclusion, when pooling the results; reporting studies with different study designs would make this much more difficult or even impossible. Exclusion criteria included: 1) animal or cell-culture
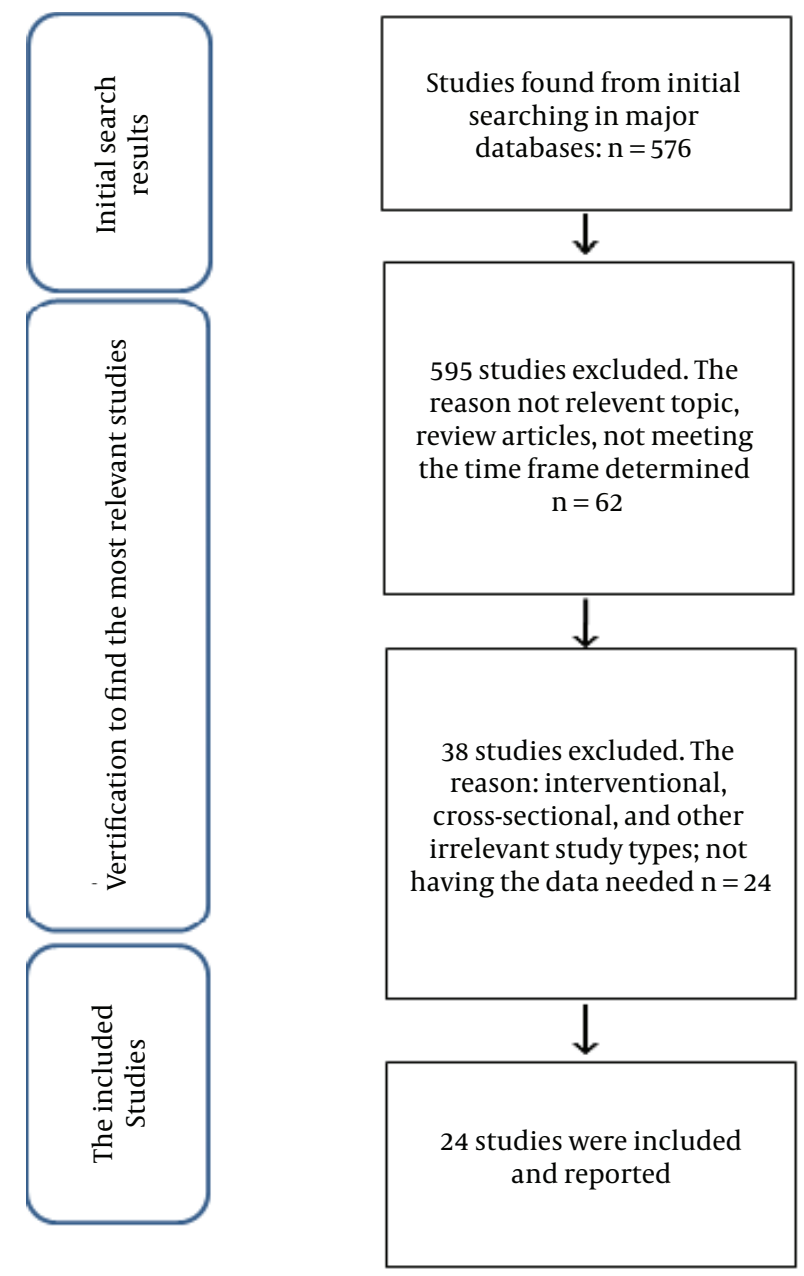

Figure 1. The Flow Diagram Showing how the Studies Were Selected and Included in the Review 
studies; 2) review studies and case reports, and 3) studies not meeting the inclusion criteria. The review was unrestricted in terms of healthy or obese/diabetic patients, as the cases/controls. Figure 1 shows the diagram according to which the articles were included or excluded from the review.

Finally, the necessary data were extracted from each article. These data included: the details needed for the reference (author, journal, year, etc.), sample size and the relevant characteristics of the cases/controls, the SNPs studied, the phenotypes (obesity-related outcomes), the particular ethnic group studied, if mentioned; the specific allele frequency and the difference between the two groups in this regard and the final conclusion that the authors made about the results of the study.

\section{Results}

Overall, 657 studies were found and filtered according to our inclusion/exclusion criteria. Out of these, 24 studies matched the criteria and were analyzed further. A total of 633 studies were excluded.

\subsection{Study Quality}

Firstly, we qualitatively analyzed the quality of the studies, which were included, in terms of sample size, data presentation, and case/control inclusion and exclusion criteria. Regarding sample size, most of the studies used fairly large enough sample size, which would enable to detect the small correlations that are of great importance in genome-related studies. However, the rationale behind determining the sample size was not always justified by the authors. Most of the studies also reported well on subject characteristics (age, gender, weight, BMI, etc.). However, the way the participants were recognized as eligible to take part in the studies (inclusion/exclusion criteria) was not always described. Concerning the obesity-related parameters, most of the studies assessed a number of them.

\subsection{Overall Results on Leptin/Leptin Receptor Genes and Ghrelin/Ghrelin Receptor Genes Single- Nucleotide Polymorphisms}

As previously mentioned, 24 studies were investigated about common SNPs on LEP/LEPR and GHRL/GHSR and their relation to obesity and its related health parameters. Of these, 17 were on LEP/LEPR SNPs and seven studies on GHRL/GHSR SNPs. The studies on LEP/LEPR were conducted on all continents (nine, eight, four, and three studies were conducted in Asia, Europe, America, and Africa, respectively). Therefore, we can say that this review covers most of the ethnic groups all around the world, making it easier to generalize the results to all healthy people worldwide. However, no studies about GHRL/GHSR were included from America and Africa in this review.

The most prevalent LEP and LEPR SNPs studied were LEP G-2548A and LEPR Q223R, respectively. However, LEPR K109R and K656N were studied more frequently. The GHRL SNP most studied was Leu72Met.

Of the seventeen articles on LEP/LEPR SNPs, nine studies reported significant association with obesity and/or its related health outcomes, or at least considered them as possible risk factors; however, eight of these studies failed to discover such relationships (1,11-26). Among LEPR SNPs, Q223R was studied in 12 studies. This polymorphism was reported to be related with obesity and/or overweight in four studies (13-16). This SNP was also stated to be a risk factor for T2DM in one study conducted on people with this condition (17).

The K109R and K656N were the other two important SNPs and their association with obesity was investigated in five and four studies, respectively. These two LEPR SNPs were reported to be related to obesity in children, in one study (13), which was not the case in adults. Another study, which studied the relationship between K109R, K656N and LEP3' flanking region polymorphism and obesity claimed that these SNPs were associated with obesity only when present simultaneously (18).

It should also be noted that four studies examined the relationship between LEPR SNPs and obesity and/or overweight in children and/or adolescents (13, 19-21). Among these, only Tabassum et al. (13) could find a significant association between Q223R, K109R and K656N and obesity in children.

The most prevalent GHRL SNP studied was Leu72Met. Of the seven studies on GHRL/GHSR SNPs (six on GHRL and one on GHSR), three studies showed significant relationship between these SNPs and obesity and/or its related health outcomes. However, four studies did not show a relationship. All of the studies on the relationship between GHRL SNPs and obesity included Leu72Met (22-28); nevertheless, only two of them (by the same author) reported a significant relationship $(22,26)$. The Arg51Gln was included in only one study, which found no association (25). Several unpopular GHRL SNPs were also investigated. Surprisingly, these SNPs (including + $3056 \mathrm{~T}>\mathrm{C}(\mathrm{rs} 2075356),-1500 \mathrm{C}>\mathrm{G}$ (rs3755777), -1062 G > C (rs26311), -994 C > T (rs26312)) were reported to be significantly related to obesity $(22,26)$. One study examined the relationship between GHSR -151 C > T SNP and obesity, which also failed to find a meaningful association (28). Also, it is noteworthy that one study that included children, as participants, could not show a relationship between Leu72Met and obesity in children (24).

A summary of the studies reviewed and their results can be found in Table 1 Table 2 . The studies are presented in chronological order (from the most recent to the least recent study). 
Table 1. Summary of Studies on Leptin/Leptin Receptor Genes and Their Association With Overweight/Obesity and Related Health Outcomes ${ }^{a}$

\begin{tabular}{|c|c|c|c|c|c|}
\hline Authors & Country & Subjects & SNP(rs Number) & Outcome & Reference \\
\hline Etemad et al. & Malaysia & $\begin{array}{l}565 \text { people ( } 284 \text { people } \\
\text { with T2DM and } 281 \\
\text { healthy individuals) }\end{array}$ & Q223R(rs1137101) & $\begin{array}{l}\text { Q223R polymorphism of LEPR might } \\
\text { be considered as a significant risk } \\
\text { factor for T2DM in Malaysians; } \\
\text { especially in Chinese ethnics }\end{array}$ & (17) \\
\hline Sahin et al. & Turkey & $\begin{array}{l}95 \text { people ( } 47 \text { obese and } \\
48 \text { healthy) }\end{array}$ & LEP G-2548A & $\begin{array}{l}\text { This LEP polymorphism was } \\
\text { associated with obesity and serum } \\
\text { leptin levels }\end{array}$ & (29) \\
\hline Lu et al. & China & $\begin{array}{l}432 \text { subjects ( } 230 \text { obese } \\
\text { and } 202 \text { normal weight) }\end{array}$ & $\begin{array}{l}\text { K109R (1137100) K656N } \\
\text { (rs8179183) LEP gene 3' flanking } \\
\text { region polymorphism }\end{array}$ & $\begin{array}{c}\text { These SNPs were significantly } \\
\text { associated with BMI only when were } \\
\text { present simultaneously }\end{array}$ & (18) \\
\hline Tabassum et al. & India & $\begin{array}{c}3168 \text { children ( } 2261 \\
\text { normal weight; } 907 \\
\text { obese/overweight) }\end{array}$ & $\begin{array}{c}\text { Q223R (rs1137101) K109R } \\
\text { (1137100) K656N (rs8179183) }\end{array}$ & $\begin{array}{l}\text { All of these LEPRSNPs were showed } \\
\text { to be significantly associated with } \\
\text { childhood obesity }\end{array}$ & (13) \\
\hline Komsu-Ornek et al. & Turkey & $\begin{array}{l}191 \text { children (92 obese } \\
\text { and } 99 \text { non-obese } \\
\text { children) }\end{array}$ & Q223R(rs1137101) & $\begin{array}{c}\text { There was no overall association } \\
\text { between Q223R polymorphism of } \\
\text { LEPR and obesity and obesity related } \\
\text { disorders }\end{array}$ & (19) \\
\hline Traurig et al. & US & 2842 Pima Indians & $\begin{array}{l}80 \text { different variants were } \\
\text { analyzed }\end{array}$ & $\begin{array}{l}\text { The variants rs } 2025804 \text {, rs } 1171274 \text {, } \\
\text { and rs6662904 were significantly } \\
\text { associated with BMI }\end{array}$ & (30) \\
\hline Boumaiza et al. & Tunisia & $\begin{array}{l}329 \text { people (160 obese } \\
\text { and } 169 \text { non-obese) }\end{array}$ & Q223R(rs1137101) LEP G-2548A & $\begin{array}{l}\text { Both variants were significantly } \\
\text { related to BMI, energy intake, TC, WC, } \\
\text { glycaemia, insulinemia and low HDL-c }\end{array}$ & $(14)$ \\
\hline Angel-Chavez et al. & Mexico & $\begin{array}{l}128 \text { children and } \\
\text { adolescents ( } 76 \text { obese/ } \\
\text { overweight and } 52 \\
\text { normal weight) }\end{array}$ & $\begin{array}{c}\text { Q223R (rs1137101) K109R } \\
\text { (1137100) K656N (rs8179183) }\end{array}$ & $\begin{array}{c}\text { There was no association between } \\
\text { these SNPs and obesity/overweight in } \\
\text { children }\end{array}$ & (20) \\
\hline Bender et al. & Switzerland & 6184 Caucasians & $\begin{array}{c}\text { Q223R (rs10889567) K109R } \\
\text { (rs1137100) K656N (rs3790437) }\end{array}$ & $\begin{array}{c}\text { There was no overall association } \\
\text { between these LEPR SNPs and } \\
\text { overweight/obesity }\end{array}$ & (1) \\
\hline Angeli et al. & Brazil & $\begin{array}{l}709 \text { people ( } 375 \text { subjects } \\
\text { of African ancestry } \\
\text { and } 334 \text { of European } \\
\text { ancestry) }\end{array}$ & Q223R(rs1137101) LEP A19G & $\begin{array}{l}\text { No overall association between these } \\
2 \text { SNPs and obesity/overweight }\end{array}$ & (31) \\
\hline Pereira et al. & Brazil & $\begin{array}{l}4193 \text { non-diabetic } \\
\text { subjects }\end{array}$ & Q223R(rs1137101) & $\begin{array}{l}\text { No special genotype was associated } \\
\text { with obesity/overweight }\end{array}$ & $(32)$ \\
\hline Ben Ali et al. & Tunisia & $\begin{array}{l}710 \text { subjects ( } 393 \text { obese } \\
\text { and } 317 \text { normal weight) }\end{array}$ & G3057A LEPR & $\begin{array}{c}\text { There was no significant difference } \\
\text { between the two groups in genotype } \\
\text { frequency }\end{array}$ & (33) \\
\hline Constantin et al. & Romania & $\begin{array}{c}202 \text { individuals (108 } \\
\text { obese and } 94 \text { non-obese) }\end{array}$ & Q223R(rs1137101) LEP G-2548A & $\begin{array}{c}\text { There was no overall association } \\
\text { between Q223R (in LEPR) and G-2548A } \\
\text { (in LEP) with obesity in Romanian } \\
\text { subjects }\end{array}$ & $(34)$ \\
\hline Murugesan et al. & India & $\begin{array}{l}300 \text { subjects ( } 150 \\
\text { diabetic and } 150 \text { non- } \\
\text { diabetic) }\end{array}$ & $\begin{array}{c}\text { Q223R (rs1137101) K109R } \\
(1137100) \text { K656N (rs8179183) }\end{array}$ & $\begin{array}{l}\text { Only Q223R was associated with BMI } \\
\text { and significantly different between } \\
\text { the two groups }\end{array}$ & $(15)$ \\
\hline Furusawa et al. & Japan & 809 Pacific Islanders & $\begin{array}{c}\text { Q223R(rs1137101) K109R(1137100) } \\
\text { LEP G-2548A }\end{array}$ & $\begin{array}{l}\text { Only Q223R was associated to BMI and } \\
\text { obesity }\end{array}$ & $(16)$ \\
\hline Ben Ali et al. & Tunisia & $\begin{array}{l}693 \text { subjects ( } 392 \text { obese } \\
\text { and } 302 \text { healthy) }\end{array}$ & Q223R(rs1137101) & $\begin{array}{l}\text { There is no overall association be- } \\
\text { tween this SNP an obesity }\end{array}$ & (35) \\
\hline Pyrzak et al. & Poland & $\begin{array}{l}152 \text { children (101 obese } \\
\text { and } 41 \text { non-obese) }\end{array}$ & Q223R(rs1137101) & $\begin{array}{l}\text { Q223R polymorphism of LEPR is not } \\
\text { associated with obesity and other } \\
\text { metabolic disturbances in children }\end{array}$ & (21) \\
\hline
\end{tabular}

\footnotetext{
a Abbreviations: BMI, body mass index; HDL-c, high density lipoprotein cholesterol; LEP, leptin; LEPR, leptin receptor genes; SNP, single nucleotide
} polymorphisms; TC, Total Cholesterol; T2DM, type 2 diabetes mellitus; WC, waist circumference. 
Table 2. Summary of Studies on Ghrelin/Ghrelin Receptor Genes Single Nucleotide Polymorphisms and Their Association With Overweight/Obesity and Related Health Outcomes ${ }^{\text {a }}$

\begin{tabular}{|c|c|c|c|c|c|}
\hline Authors & Country & Subjects & SNP (rs Number) & Outcome & Reference \\
\hline Takezawa et al. & Japan & 117 obese women & $\begin{array}{c}-1500 \mathrm{C}>\mathrm{G}(\mathrm{rs} 3755777) 1062 \mathrm{G}> \\
\mathrm{C}(\mathrm{rs} 26311)-994 \mathrm{C}>\mathrm{T}(\mathrm{rs} 26312) \\
\text { Leu72Met }(\mathrm{rs} 696217)+3056 \mathrm{~T}>\mathrm{C} \\
(\mathrm{rs} 2075356)\end{array}$ & $\begin{array}{c}\text { All these variants in ghrelin gene } \\
\text { were associated with obesity } \\
\text { parameters }\end{array}$ & $(22)$ \\
\hline Liu et al. & China & $\begin{array}{l}1741 \text { subjects ( } 877 \text { subjects with } \\
\text { T2DM and } 864 \text { healthy subjects) }\end{array}$ & Leu72Met(rs696217) & $\begin{array}{l}\text { There seems to be no significant } \\
\text { difference in Leu72Met distribution } \\
\text { between the two groups }\end{array}$ & (23) \\
\hline Zhu et al. & China & $\begin{array}{c}330 \text { children ( } 230 \text { obese and } 100 \\
\text { non-obese children })\end{array}$ & Leu72Met(rs696217) & $\begin{array}{l}\text { There seems to be no significant } \\
\text { difference in Leu72Met distribution } \\
\text { between the two groups }\end{array}$ & $(24)$ \\
\hline Leskela et al. & Finland & $\begin{array}{l}23 \mathrm{MZ} \text { twins discordant for obesity } \\
\text { (controls); } 43 \mathrm{MZ} \text { twins concordant } \\
\text { for normal BMI and } 46 \mathrm{MZ} \text { twins } \\
\text { concordant for obesity }\end{array}$ & Leu72Met (rs696217) Arg51Gln & $\begin{array}{l}\text { These ghrelin polymorphisms do } \\
\text { not affect neither total serum con- } \\
\text { centration of ghrelin nor the obesity } \\
\text { predisposition }\end{array}$ & $(25)$ \\
\hline Takezawa et al. & Japan & $\begin{array}{l}235 \text { overweight/obese individuals } \\
\text { (compared to healthy individuals } \\
\text { in HapMap project or other studies } \\
\text { analyzing east Asians }\end{array}$ & $\begin{array}{c}-1500 \mathrm{C}>\mathrm{G}(\mathrm{rs} 3755777)-1062 \mathrm{G} \\
>\mathrm{C}(\mathrm{rs} 26311)-994 \mathrm{C}>\mathrm{T}(\mathrm{rs} 26312) \\
\text { Leu72Met }(\mathrm{rs} 696217)+3056 \mathrm{~T}>\mathrm{C} \\
(\mathrm{rs} 2075356)\end{array}$ & $\begin{array}{l}\text { These SNPs are shown to be related } \\
\text { to obesity and its related lipidemic } \\
\text { and glycemic parameters }\end{array}$ & $(26)$ \\
\hline Berthold et al. & Germany & $\begin{array}{l}850 \text { Caucasians (420 subjects with } \\
\text { T2DM and } 430 \text { healthy subjects) }\end{array}$ & Leu72Met(rs696217) & $\begin{array}{l}\text { Leu72Met was associated negatively } \\
\text { with T2DM }\end{array}$ & $(27)$ \\
\hline Gjesing et al. & Denmark & $\begin{array}{l}15854 \text { unrelated, middle-aged } \\
\text { individuals }\end{array}$ & $\begin{array}{l}\text { Seven SNPs were investigated; } \\
\text { among them: GHSR-151C> T }\end{array}$ & $\begin{array}{c}\text { None of these SNPs were related to } \\
\text { quantitative factors of obesity }\end{array}$ & $(28)$ \\
\hline
\end{tabular}

a Abbreviations: BMI, body mass index; GHSR, ghrelin/ghrelin receptor genes; MZ, monozygote; SNP, single nucleotide polymorphisms; T2DM, type 2 diabetes mellitus.

\section{Conclusions}

In this article, we reviewed several of the potential SNPs related to energy homeostasis and, consequently, to obesity and the metabolic disorders related to them. These included the genes coding LEP and LEPR and GHRL and GHSR. Of the seventeen articles on LEP/LEPR SNPs, nine studies reported a significant association or at least considered them as possible risk factors; however, eight of these studies failed to discover such a relationship (1, 11-26). Of the seven studies on GHRL/GHSR SNPs (six on GHRL and one on GHSR), three studies showed significant relationship between these SNPs and obesity and/or its related health outcomes, while four other studies did not show a relationship (22-28).

\subsection{Overview of Other Studies}

Many studies have been conducted on LEP/LEPR and GHRL/GHSR polymorphisms and the effects they may exert on body weight and metabolic disturbances. Since we decided to investigate only the case-control studies published in a particular time period, many of them went unreported in this paper.

Bender et al. conducted a meta-analysis on 55 studies (17 case-control and 38 single group studies) to investigate the relationship between common SNPs of LEPR and overweight (1). These studies were on different races/ ethnic groups, including Caucasians, Asians, African, and of mixed ancestry. The most studied SNP, just like in our study, was Q223R. This meta-analysis reported no significant association between LEPR SNPs and overweight, when the data of these studies were pooled; however, several studies, which were analyzed, reported a series of significant associations with markers of overweight/obesity. In another review article by M. Phillips, rs3790433 polymorphism of LEPR was reported to be associated with the risk of metabolic syndrome and insulin resistance (11).

Although we just reported case-control studies, interventional studies are of great importance, when it comes to determining the effects of a gene polymorphism on one's response to dietary intervention. In a review article by Basic et al., it was reported that a polymorphism in the -2549 position in the promoter region of the LEP gene is associated with obesity and that the carriers of -2549A allele lose less weight in response to a low calorie diet. It was also stated that carriers of the C allele of T343C polymorphism of LEPR lose more weight compared to the non-carriers. Another study in this article reported that Lys656 homozygotes for Lys656Asn polymorphism had a significant loss of body weight, waist circumference, decreased BMI, systolic blood pressure, and leptin levels, in response to a dietary intervention, when compared to carriers of Asn656 (2). Another review article by Rud- 
kowskaand and Perusse investigated the effects of several common LEPR SNPs on the participants' response to low calorie diets. This article did report the same about the effect T343C polymorphism on weight loss, following a dietary intervention. Another LEP polymorphism, which was investigated in this article, is 3'UTR insertion/deletion; it was reported that the carriers of the I-allele lost greater weight compared to non-carriers. This article also supported that Asn656 allele carriers were more resistant to dietary intervention. Another study reported by this same article showed that Q223R and K109R SNPs of LEPR make people more susceptible to T2DM, although they do not show any relationship with weight loss after a 3-year diet and exercise program (6).

Several review articles also investigated the relationship between GHRL/GHSR polymorphisms and overweight/ obesity and related metabolic disturbances. Pulkkinen et al. investigated the most studied SNPs in GHRL/GHSR. Just like our findings, Leu72Met and Arg51Gln were the two most studied SNPs. There have been contradictory results regarding this relationship; several studies proposed that Met72 allele of GHRL was associated with earlier age at onset of obesity and higher BMI, while an inverse relationship has also been reported. This situation resembles the finding of our study. The other SNPs most studied were $-501 \mathrm{~A}>\mathrm{C}$ and $+3056 \mathrm{~T}>\mathrm{C}$; inconsistent results were also reported regarding the effect that these SNPs may exert on body weight. This review also stated that, according to the studies, GHRL variations may have several effects on blood pressure. The GHSR polymorphisms were also shown to be inconsistently associated with features of metabolic syndrome (36). Seven GHSR polymorphisms were analyzed for their role in obesity in the participants of Finnish Diabetes Prevention Study; results show that people with rs490683 C/C genotype were more prone to lose more weight after a 3-year diet and exercise intervention (6).

Taking into account the results of our study and other studies reviewed above, it can be easily understood that giving a sure statement about the association of these SNPs and obesity and its related diseases is no way reasonable. There are several proposed reasons why such contradictory results are seen: 1 ) the different environmental exposures, which are shown to affect the way genes are expressed (such as nutrient intake) (6), 2) inconsistent methods and criteria used to classify individuals as overweight/obese or lean/normal, 3) unjustified and arbitrary strategies in determining the sample size, and 4) inconsistent genotyping methods, with different precisions, to detect the specific SNP. Besides discovering these associations, there are many controversies that necessitate further studies on this subject: 1) if such a relationship between these SNPs and overweight/obesity really exists; can this specific allele be regarded as an actual risk factor? Answering this question will make researchers and governments determine the prevalence of these SNPs in each and every society. A risk allele will lose its significance when it is not common enough in a particular population, no matter how strongly associated with obesity; 2) what is the real risk SNP, and more specifically, the real risk allele. Even though we reported the most studied SNPs, this does not necessarily mean that they are the actual risk SNPs. Even the real risk allele, in each specific SNP, is not yet fully appreciated; e.g. several studies reported that Met72 is the risk allele in Leu72Met polymorphism of GHRL, while other studies also reported this SNP and allele as protective factors $(10,27,36)$. This is also the case in Q223R; contrary to most of the studies, one study reported the Q allele as the risk allele (16).

This study has the following limitations: 1 ) only studies published between 2009 to the time that this study was conducted were included, 2) the studies included were not filtered regarding their sample sizes, and 3) unfortunately, due to limited number of studies related to each ethnicity, these findings cannot help us discover more about the effect that each SNP may exert in different races and ethnicities.

In this study, we reviewed a total 24 case-control studies, published from 2009 to present. Of these, 17 studies were on LEP/LEPR and seven studies were on GHRL/GHSR and their association with overweight/obesity and/or its related metabolic disturbances. Although several studies show certain relationships, the results were inconclusive and sometimes contradictory. The real association of these SNPs with obesity remains to be clarified and warrants further research and meta-analyses. Our review failed to detect a consistent correlation between these gene polymorphisms and metabolic disturbances, which, in part, may be due to a series of unidentified environmental interactions and possibly the effects that inter-individual variations in nutrient intake might have in gene expression (the nutrigenomics). It should also be noted that case-control studies usually fail to discover clear cause-and-effect relationships and, since we reviewed only case-control studies, this is one of the limitations of our study. Besides case-control studies, a very important amount of work needs to be done in clinical trials to further elucidate the effects of these polymorphisms on different individuals' responses to dietary interventions.

\section{Authors' Contributions}

Study concept and design, acquisition of data, analysis and interpretation of data, drafting of the manuscript: Hamid Ghalandari. Critical revision of the manuscript for important intellectual content; administrative, technical, and material support; study supervision: Parvin Mirmiran, Firoozeh Hosseini-Esfahani.

\section{References}

1. Bender N, Allemann N, Marek D, Vollenweider P, Waeber G, Mooser $\mathrm{V}$, et al. Association between variants of the leptin receptor gene (LEPR) and overweight: a systematic review and an analysis of the CoLaus study. PLoS One. 2011;6(10):e26157. 
2. Basic M, Butorac A, Landeka Jurcevic I, Bacun-Druzina V. Obesity: genome and environment interactions. Arh Hig Rada Toksikol. 2012;63(3):395-405.

3. Shahbazpour N. Prevalence of Overweight and Obesity and Their Relation to Hypertension in Adult Male University Students in Kerman, Iran. Int JEndocrinol Metabol. 2003;1(2):55-60.

4. Shenavar R, Kalantari N, Rashidkhani B, Hooshyarrad A. Determination of The Primary Reasons For Overweight and Obesity Among First Grade Elementary School Students in Shiraz During The Academic Year 2010-2011. Int J Endocrinol Metabol. 2014;1(1):e20229.

5. Liu L, Zhao X, Kang S, Zhang D. An association between -866G/A polymorphism in the promoter of UCP2 and obesity: a metaanalysis. Gene. 2013;514(1):41-7.

6. Rudkowska I, Perusse L. Individualized weight management: what can be learned from nutrigenomics and nutrigenetics? Prog Mol Biol Transl Sci. 2012;108:347-82.

7. McNiven EM, German JB, Slupsky CM. Analytical metabolomics: nutritional opportunities for personalized health. $J$ Nutr Biochem. 2011;22(11):995-1002.

8. Hamada T, Kotani K, Fujiwara S, Sano Y, Domichi M, Tsuzaki K, et al. The common $-55 \mathrm{C} / \mathrm{T}$ polymorphism in the promoter region of the uncoupling protein 3 gene reduces prevalence of obesity and elevates serum high-density lipoprotein cholesterol levels in the general Japanese population. Metabolism. 2008;57(3):410-5.

9. Costa V, Casamassimi A, Ciccodicola A. Nutritional genomics era: opportunities toward a genome-tailored nutritional regimen. $J$ Nutr Biochem. 2010;21(6):457-67.

10. Loktionov A. Common gene polymorphisms and nutrition: emerging links with pathogenesis of multifactorial chronic diseases (review). J Nutr Biochem. 2003;14(8):426-51.

11. Phillips CM. Nutrigenetics and metabolic disease: current status and implications for personalised nutrition. Nutrients. 2013;5(1):32-57.

12. Neary NM, Goldstone AP, Bloom SR. Appetite regulation: from the gut to the hypothalamus. Clin Endocrinol (Oxf). 2004;60(2):153-60.

13. Tabassum R, Mahendran Y, Dwivedi OP, Chauhan G, Ghosh S, Marwaha RK, et al. Common variants of IL6, LEPR, and PBEF1 are associated with obesity in Indian children. Diabetes. 2012;61(3):626-31.

14. Boumaiza I, Omezzine A, Rejeb J, Rebhi L, Ben Rejeb N, Nabli N, et al. Association between four resistin polymorphisms, obesity, and metabolic syndrome parameters in Tunisian volunteers. Genet Test Mol Biomarkers. 2012;16(12):1356-62.

15. Murugesan D, Arunachalam T, Ramamurthy V, Subramanian S. Association of polymorphisms in leptin receptor gene with obesity and type 2 diabetes in the local population of Coimbatore. Indian J Hum Genet. 2010;16(2):72-7.

16. Furusawa T, Naka I, Yamauchi T, Natsuhara K, Kimura R, Nakazawa M, et al. The Q223R polymorphism in LEPR is associated with obesity in Pacific Islanders. Hum Genet. 2010;127(3):287-94.

17. Etemad A, Ramachandran V, Pishva SR, Heidari F, Aziz AF, Yusof AK, et al. Analysis of Gln223Agr polymorphism of Leptin Receptor Gene in type II diabetic mellitus subjects among Malaysians. Int J Mol Sci. 2013;14(9):19230-44.

18. Lu J, Zou D, Zheng L, Chen G, Lu J, Feng Z. Synergistic effect of LEP and LEPR gene polymorphism on body mass index in a Chinese population. Obes Res Clin Pract. 2013;7(6):e445-9.

19. Komsu-Ornek Z, Demirel F, Dursun A, Ermis B, Piskin E, Bideci A Leptin receptor gene Gln223Arg polymorphism is not associated with obesity and metabolic syndrome in Turkish children. Turk J
Pediatr. 2012;54(1):20-4.

20. Angel-Chavez LI, Tene-Perez CE, Castro E. Leptin receptor gene K656N polymorphism is associated with low body fat levels and elevated high-density cholesterol levels in Mexican children and adolescents. Endocr Res. 2012;37(3):124-34.

21. Pyrzak B, Wisniewska A, Kucharska A, Wasik M, Demkow U. No association of LEPR Gln223Arg polymorphism with leptin, obesity or metabolic disturbances in children. Eur J Med Res. 2009;14 Suppl 4:201-4.

22. Takezawa J, Yamada K, Miyachi M, Morita A, Aiba N, Sasaki S, et al Preproghrelin gene polymorphisms in obese Japanese women. Minor homozygotes are light eaters, do not prefer protein or fat, and apparently have a poor appetite. Appetite. 2013;63:105-11.

23. Liu J, Liu J, Tian LM, Liu JX, Bing YJ, Zhang JP, et al. Association of ghrelin Leu72Met polymorphism with type 2 diabetes mellitus in Chinese population. Gene. 2012;504(2):309-12.

24. Zhu JF, Liang L, Zou CC, Fu JF. Plasma ghrelin levels and polymorphisms of ghrelin gene in Chinese obese children and adolescents. Ir J Med Sci. 2010;179(3):345-9.

25. Leskela P, Ukkola O, Vartiainen J, Ronnemaa T, Kaprio J, Bouchard $\mathrm{C}$, et al. Fasting plasma total ghrelin concentrations in monozygotic twins discordant for obesity. Metabolism. 2009;58(2):174-9.

26. Takezawa J, Yamada K, Morita A, Aiba N, Watanabe S. Preproghrelin gene polymorphisms in obese Japanese: Association with diabetes mellitus in men and with metabolic syndrome parameters in women. Obes Res Clin Pract. 2009;3(4):179-91.

27. Berthold HK, Giannakidou E, Krone W, Mantzoros CS, Gouni-Berthold I. The Leu72Met polymorphism of the ghrelin gene is associated with a decreased risk for type 2 diabetes. Clin Chim Acta. 2009;399(1-2):112-6.

28. Gjesing AP, Larsen LH, Torekov SS, Hainerova IA, Kapur R, Johansen A, et al. Family and population-based studies of variation within the ghrelin receptor locus in relation to measures of obesity. PLoS One. 2010;5(4):e10084.

29. Sahin DS, Tumer C, Demir C, Celik MM, Celik M, Ucar E, et al. Association with leptin gene C.-2548 G>A polymorphism, serum leptin levels, and body mass index in Turkish obese patients. Cell Biochem Biophys. 2013;65(2):243-7.

30. Traurig MT, Perez JM, Ma L, Bian L, Kobes S, Hanson RL, et al. Variants in the LEPR gene are nominally associated with higher BMI and lower 24-h energy expenditure in Pima Indians. Obesity (Silver Spring). 2012;20(12):2426-30.

31. Angeli CB, Kimura L, Auricchio MT, Vicente JP, Mattevi VS, Zembrzuski VM, et al. Multilocus analyses of seven candidate genes suggest interacting pathways for obesity-related traits in Brazilian populations. Obesity (Silver Spring). 2011;19(6):1244-51.

32. Pereira TV, Mingroni-Netto RC, Yamada Y. ADRB2 and LEPR gene polymorphisms: synergistic effects on the risk of obesity in Japanese. Obesity (Silver Spring). 2011;19(7):1523-7.

33. Ben Ali S, Sediri Y, Kallel A, Ftouhi B, Haj-Taib S, Omar S, et al. The G3057A LEPR polymorphism is associated with obesity in Tunisian women. Nutr Metab Cardiovasc Dis. 2011;21(8):591-6.

34. Constantin A, Costache G, Sima AV, Glavce CS, Vladica M, Popov DL. Leptin G-2548A and leptin receptor Q223R gene polymorphisms are not associated with obesity in Romanian subjects. Biochem Biophys Res Commun. 2010;391(1):282-6.

35. Ben Ali S, Kallel A, Sediri Y, Ftouhi B, Feki M, Slimene H, et al. LEPR p.Q223R Polymorphism influences plasma leptin levels and body mass index in Tunisian obese patients. Arch Med Res. 2009;40(3):186-90.

36. Pulkkinen L, Ukkola O, Kolehmainen M, Uusitupa M. Ghrelin in diabetes and metabolic syndrome. Int J Pept. 2010:e248948 